\title{
Kronika Katedry Nauk Historyczno-Prawnych (rok 2012)
}

\section{Sprawy kadrowe}

\section{Zatrudnienie prof. Adama Czarnoty}

Wraz z rozpoczęciem roku akademickiego 2012/2013 do grona pracowników Katedry dołączył dr Adam Czarnota, zatrudniony na stanowisku profesora UwB. A. Czarnota specjalizuje się $w$ historii myśli prawnej, prawie porównawczym oraz teorii i socjologii prawa. Przez wiele lat pracował naukowo w Australii na Macquare University w Sydney, a następnie był profesorem prawa na Uniwersytecie Nowej Południowej Walii w Sydney. Pełnił tam funkcje kierownika European Law Center oraz dyrektora Center for the Interdisciplinary Studies of Law. Prowadził wykłady z historii prawa, teorii prawa i prawa porównawczego na różnych uczelniach w Australii, Kanadzie, USA, RPA, Brazylii, Belgii, na Węgrzech, w Wielkiej Brytanii oraz Hiszpanii. W latach 2006-2008 pracował jako senior fellow w Royal Flemish Academy of Sciences and Arts (Belgia), a także jako fellow w Collegium Budapest/Institute for Advanced Studies. Od września 2013 r. pełni funkcję dyrektora naukowego Międzynarodowego Instytutu Socjologii Prawa z siedzibą w Oniati (Hiszpania) oraz jest profesorem na Wydziale Prawa Uniwersytetu Kraju Basków w San Sebastian.

\section{Obrona Diany Maksimiuk}

W dniu 25 kwietnia 2012 r. odbyła się obrona rozprawy doktorskiej Diany Maksimiuk pt. Rok 1956 w Polsce: sqdy, prokuratury, prawo karne, napisanej pod kierunkiem prof. dr. hab. Adama Lityńskiego. Recenzentami w przewodzie doktorskim byli dr hab. Marian Mikołajczyk (UŚ) oraz prof. dr hab. Dorota Malec (UJ). Rada Wydziału Prawa UwB podjęła jednomyślną uchwałę o nadaniu Dianie Maksimiuk stopnia naukowego doktora.

\section{Publikacje}

W 2012 r. ukazała się drukiem rozprawa doktorska Piotra Kołodki Ustawodawstwo rzymskie w sprawach karnych: od ustawy XII tablic do dyktatury Sulli (wyd. Temida2). Piotr Fiedorczyk jest autorem rozdziału Počátky socialistického rodinného práva w książce Vývoj soukromého práva na území českých zemí (red. L. Vojáček, K. Schelle, J. Tauchen, Brno 2012). Natomiast w opracowaniu Wydział Prawa Uniwersytetu w Białymstoku w fotografiach 1972-2012 (red. 
P. Fiedorczyk, J. Banasiuk, A. Bujakowska, P. A. Jamróz, Białystok 2012) zamieścił rozdział Dzieje budynku Wydziału Prawa oraz jest współautorem rozdziału Historia Wydziału Prawa.

Artykuły pracowników Katedry opublikowane zostały w zagranicznych i krajowych periodykach naukowych oraz pracach zbiorowych. W czasopiśmie "International Journal of the Jurisprudence of the Family" (2012, vol. 3) ukazał się artykuł Piotra Fiedorczyka Attempts at Redefining the Family in Contemporary Polish Law. Ponadto Piotr Fiedorczyk publikował na łamach czeskiego periodyku naukowego „Právo, Ekonomika, Management”, gdzie zamieścił artykuł O počátcích socialistického rodinného práva (cz. 1: „Právo, Ekonomika, Management” 2011, nr 4 oraz cz. 2: „Právo, Ekonomika, Management" 2012, nr 1).

Na łamach "Czasopisma Prawno-Historycznego" (CPH 2012, t. LXIV, z. 2) Marcin Łysko opublikował artykuł Kształtowanie się ustroju kolegiów orzekających w Polsce Ludowej (1952-1956). Piotr Niczyporuk zamieścił artykuł Rozważania Wolfganga Waldsteina o dziecku poczętym w pracy zbiorowej Interes prywatny a interes publiczny w prawie rzymskim (red. B. Sitek, K. Naumowicz, Olsztyn 2012).

Pracownicy Katedry publikowali także w księgach pamiątkowych dedykowanych wybitnym postaciom nauk historyczno-prawnych. W wydanej nakładem wydawnictwa Temida2 księdze pamiątkowej prof. Marii Szyszkowskiej (Filozofia Marii Szyszkowskiej. Ksiegga Dedykowana, red. A. Kryniecka, Białystok 2012) swoje artykuły zamieścili: Florian Lempa (Problematyka pokoju w pogladach Marii Szyszkowskiej), Piotr Fiedorczyk (Kilka uwag o publicznej dyskusji nad prawem rodzinnym w projekcie kodeksu cywilnego z 1960 r.) oraz Karol Kuźmicz (Inspiracje kantowskie w Marii Szyszkowskiej filozofii prawa). W księdze jubileuszowej prof. Stanisława Prutisa ( $Z$ zagadnień prawa rolnego, cywilnego i samorzadu terytorialnego. Księga jubileuszowa Profesora Stanistawa Prutisa, red. J. Bieluk, T. Mróz, A. Doliwa, A. Malarewicz-Jakubów, Białystok 2012) Piotr Fiedorczyk opublikował artykuł O podziałach administracyjnych w województwie biatostockim w okresie międzywojennym, natomiast Piotr Niczyporuk artykuł Aukcyjna sprzedaż majątków z udziatem bankierów w starożytnym Rzymie. Ponadto Florian Lempa ogłosił drukiem artykuły Kardynat Zenon Grocholewski - naukowiec i praktyk w służbie Kościoła katolickiego w pracy (Polska myśl prawnicza w XIX i XX wieku, red. P. Majer, M. Seroka, K. M. Wojciechowski, Olsztyn 2012) oraz Omnium Horarum Omnibus Homo w księdze poświęconej Tadeuszowi Płoskiemu (Wspomnienia o Tadeuszu Płoskim - biskupie, generale i profesorze, red. Z. Kępa, M. Seroka, Olsztyn-Warszawa 2012), a Piotr Fiedorczyk artykuł Echa projektów unifikacji osobowego prawa małżeńskiego w II RP na terenie województwa białostockiego w księdze jubileuszowej prof. Jerzego Malca (Regnare, gubernare, administrare. Prawo i władza na przestrzeni wieków. Prace dedykowane profesorowi Jerzemu Malcowi z okazji 40-lecia pracy naukowej, red. S. Grodziski, A. Dziadzio, Kraków 2012). 


\section{Udział w konferencjach naukowych}

W 2012 r. pracownicy Katedry brali udział w wielu zagranicznych i krajowych konferencjach naukowych, wygłaszając w ich trakcie referaty. Florian Lempa uczestniczył w VIII Colloquium Prawno-Historycznym „Ius belli et pacis w tradycji europejskiej” (Brzeg, kwiecień 2012 r.), prezentując referat Konfrontacja nauczania Ojców Kościoła pierwszych wieków z rzymska doktryna wojny sprawiedliwej (iustum bellum), a także w konferencji „Prawa Dziecka (nie) poczętego" (Olsztyn, kwiecień 2012 r.), gdzie wygłosił referat Autentyczna interpretacja kanonu 1398 kodeksu prawa kanonicznego z 1983 r. przez Papieska Radę do spraw interpretacji tekstów prawnych.

Na przełomie kwietnia i maja 2012 r. Piotr Fiedorczyk uczestniczył w dwóch zagranicznych konferencjach naukowych, z których pierwsza - „Parents and Children - an Evolving Relationship" odbyła się w Reggio Emilia (Włochy). Wystąpił tam z referatem The 2012 Changes in the Adoption Proceedings in Poland. Kolejna konferencja - „Symposium on the Jurisprudence of Extended Families, Extending Families and Intergenerational Solidarity" miała miejsce w stolicy Kataru Dausze, gdzie Piotr Fiedorczyk wygłosił referat The Consequences of the Attempts to Redefine the Notion of Family in Polish Law.

Florian Lempa brał udział w Międzynarodowej Konferencji Naukowej „La libertà: diritto o utopia?" (Warszawa, maj 2012 r.), gdzie wystąpił z referatem Znaczenie demokracji bezpośredniej w państwie prawa. Podczas tej samej konferencji Krzysztof Szczygielski wygłosił referat Ius patronatus w prawie rzymskim. Podczas Międzynarodowej Konferencji Romanistycznej „Interes prywatny a interes publiczny w prawie rzymskim. Współczesne spostrzeżenia" (Kętrzyn, maj 2012 r.), Florian Lempa przedstawił referat Ewolucja koncepcji wojny ab bello iusto ad bellum preventivu, natomiast Piotr Niczyporuk wygłosił referat Rozważania Wolfganga Waldsteina w przedmiocie dziecka poczętego.

Pracownicy Katedry uczestniczyli w zorganizowanej na Wydziale Prawa UwB pod koniec maja 2012 r. Międzynarodowej Konferencji Naukowej „Wolność i formy ochrony wolności", wygłaszając następujące referaty:

- Piotr Kołodko, Czy w prawie rzymskim można poszukiwać wolności gospodarczej?;

- Karol Kuźmicz, Wolność jako kategoria filozoficzno-prawna;

- Florian Lempa, Zgoda małżeńska a wolność osobista;

- Piotr Niczyporuk, Wolność a poczęcie w prawie rzymskim;

- Krzysztof Szczygielski, Prawo do kontaktów z dziećmi i jego ochrona w polskim systemie prawnym.

Piotr Niczyporuk uczestniczył w Międzynarodowej Konferencji „Diritto romano pubblico e privato: l'esperienza plurisecolare dello sviluppo del diritto europeo", która odbyła się na początku czerwca 2012 r. w Nowosibirsku. Podczas tej konferencji wygłosił referat w języku rosyjskim Государственные 
и иастные банкирь в Аревнем Риме. W V Międzynarodowym Sympozjum „Z dziejów biurokracji” (Toruń, czerwiec 2012 r.) udział wzięli Marcin Łysko (referat Aparat biurokratyczny orzecznictwa karno-administracyjnego Polski Ludowej) oraz Mariusz Mohyluk, który wygłosił referat Biurokracja w poglądach Lenina.

Podczas XXIV Ogólnopolskiego Zjazdu Historyków Prawa „Prawo a polityka. Polityczne uwarunkowania prawa czy prawne uwarunkowania polityki?”, który miał miejsce we wrześniu 2012 r. w Łodzi, z referatami wystąpili następujący pracownicy Katedry:

- Karol Kuźmicz, Prawo w utopiach komunizujących. Od nihilizmu do instrumentalizacji prawa;

- Florian Lempa, Problem granic politycznego zaangażowania Kościoła;

- Marcin Łysko, Polityczne uwarunkowania orzecznictwa karno-administracyjnego Polski Ludowej;

- Piotr Niczyporuk, Bankierzy publiczni w starożytnym Rzymie;

- Krzysztof Szczygielski, Polityka spoteczna cesarza Augusta;

- Jarosław Wołkonowski, Sytuacja mniejszości narodowych w Europie: polityka i prawo.

W październiku 2012 r. Florian Lempa uczestniczył we włoskim Bari w konferencji "Etica della pace”, gdzie przedstawił referat Etica della pace e guerra giusta? Pracownicy Zakładu Prawa Rzymskiego i Kanonicznego brali udział w Międzynarodowej Konferencji Naukowej „La pace: un impegno etico” (Bari, listopad 2012 r.), gdzie wygłosili w języku włoskim następujące referaty: Florian Lempa, L'insegnamento del Vaticano Secondo sulla pace; Krzysztof Szczygielski, Il ruolo della famiglia nell'educazione alla pace.

Podczas IX Międzynarodowej Konferencji Naukowej „Prawo a życie”, która odbyła się na Wydziale Prawa UwB w listopadzie 2012 r., z referatami wystąpili:

- Karol Kuźmicz, Na czym polega wyjątkowość życia filozofa?;

- Florian Lempa, Wartość pokoju w myśli Marii Szyszkowskiej;

- Marcin Łysko, Orzecznictwo karno-administracyjne Polski Ludowej wobec problemów życia codziennego;

- Piotr Niczyporuk, Ochrona życia dziecka poczętego w prawie rzymskim. W zorganizowanym na początku grudnia 2012 r. w Rzymie przez Libera Università Maria SS. Assunta (Lumsa) seminarium „IX Seminario del fondamenti di diritto europeo - I principi non negoziabili - curator ventris tra storia e attualità", Piotr Niczyporuk wystąpił z referatem Il curator ventris in diritto romano e in Polonia oggi.

Ponadto Karol Kuźmicz brał udział w:

- Konferencji Naukowej „Edward Abramowski oraz znaczenie spółdzielczości w dobie globalizacji" (Nałęczów, marzec 2012 r.), wystąpienie Dlaczego kooperatywizm nie powinien być utopią?; 
- I Ogólnopolskiej Konferencji Naukowej „Oblicza utopii i obłudy” (Łańsk, maj 2012 r.), wystąpienie Istota utopii komunizujących;

- XII Ogólnopolskiej Konferencji „Niezbędność filozofii w kształtowaniu społeczeństwa obywatelskiego" (Kuźnica na Helu, październik 2012 r.), podczas której wygłosił referat Nowe perspektywy filozofii wobec idei społeczeństwa obywatelskiego.

\section{Granty, kwerendy naukowe i wykłady zagraniczne}

W 2012 r. Marcin Łysko realizował grant badawczy własny Prawo karno-administracyjne Polski Ludowej 1951-1971. Piotr Fiedorczyk uczestniczył jako tzw. National Reporter w grancie The Common Core of the European Private Law, w sekcji: Duties of Care and Duties of Cash in Family Law. Ponadto wspólnie z dr hab. K. Bagan-Kurlutą pełnił funkcję tzw. National Reporter w programie Simplification of Debt Collection in the EU - grancie prowadzonym przez Wydział Prawa Uniwersytetu w Mariborze (Słowenia). Był także National Reporter w projekcie Dimensions of Evidence - złożonym przez Wydział Prawa Uniwersytetu w Mariborze wniosku o grant UE nt. europejskiego postępowania dowodowego $\mathrm{w}$ procesie cywilnym.

W ramach LLP-Erasmus - The Lifelong Learning Programme, Piotr Kołodko wspólnie z Piotrem Niczyporukiem przebywali na przełomie stycznia i lutego 2012 r. w Rzymie, gdzie przeprowadzili kwerendę badawczą w Ośrodku Dokumentacji i Studium Pontyfikatu Jana Pawła II. Podczas tego pobytu Piotr Niczyporuk wygłosił wykład w języku włoskim na studiach podyplomowych z prawa rzymskiego (Corso di Alta Formazione in Diritto Romano), prowadzonych na Uniwersytecie „La Sapienza” w Rzymie, w ramach działu Personae - pt. Sytuacja prawna dziecka poczętego w polskim porzadku prawnym z perspektywy romanistycznej. Ponadto dwukrotnie (w czerwcu i listopadzie 2012 r.) Piotr Kołodko wraz z Piotrem Niczyporukiem wyjeżdżali w celu przeprowadzenia kwerendy na Università degli Studi di Roma („La Sapienza”) w Rzymie. $Z$ kolei Florian Lempa udał się na Università degli Studi di Bari Aldo Moro, gdzie wygłosił wykłady: Globalization and idea of peace in teaching of the Popes (październik 2012 r.) oraz Ethics of peace in the doctrine of the Catholic Church (listopad 2012 r.). 